\title{
Concentrations of toxic heavy metals and trace elements in raw milk of Simmental and Holstein-Friesian cows from organic farm
}

\author{
Renata Pilarczyk • Jerzy Wójcik • Pawel Czerniak • \\ Piotr Sablik • Bogumila Pilarczyk • \\ Agnieszka Tomza-Marciniak
}

Received: 7 November 2012 / Accepted: 26 March 2013 / Published online: 10 April 2013

(C) The Author(s) 2013. This article is published with open access at Springerlink.com

\begin{abstract}
Concentrations of toxic heavy metals (cadmium $(\mathrm{Cd})$, lead $(\mathrm{Pb})$ ) and major nutritional and trace elements $(\mathrm{Ca}, \mathrm{Mg}, \mathrm{P}, \mathrm{Cu}, \mathrm{Fe}, \mathrm{Mn}, \mathrm{Se}, \mathrm{Zn})$ were analyzed in the milk of Simmental $(n=20)$ and Holstein-Friesian $(n=20)$ cows from an organic farm. Elements were determined using inductively coupled plasma emission atomic spectrometry. The conducted research showed that the milk of Simmental cows was characterized by the more advantageous mineral composition and lower concentration of noxious heavy metals compared to the milk of Holstein-Friesian cows. In the milk of Simmental cows, significantly lower concentrations of $\mathrm{Pb}$ and $\mathrm{Cd}(P<0.001)$ and $\mathrm{Cu}$ $(P<0.05)$ and significantly higher concentrations of $\mathrm{Fe}$ and $\mathrm{Mg}(P<0.05)$ as well as nonsignificantly higher concentrations of $\mathrm{Ca}, \mathrm{Mn}$, and $\mathrm{Se}$ were found. In the milk of both breeds, very low $\mathrm{Cu}$ concentrations were recorded. The higher-than-recommended concentration of $\mathrm{Pb}$ in milk was also found. In the milk of both
\end{abstract}

R. Pilarczyk $(\bowtie) \cdot$ J. Wójcik $\cdot$ P. Czerniak $\cdot$ P. Sablik Department of Ruminant Science, West Pomeranian University of Technology in Szczecin,

Judyma 10 Street,

71-460 Szczecin, Poland

e-mail: renata.pilarczyk@zut.edu.pl

B. Pilarczyk · A. Tomza-Marciniak

Department of Animal Reproduction Biotechnology and Environmental Hygiene, West Pomeranian University of Technology in Szczecin,

Judyma 6 Street,

71-460 Szczecin, Poland breeds, the significant positive correlations between concentrations of the following elements were observed: $\mathrm{Pb}-\mathrm{Cd}, \mathrm{Pb}-\mathrm{Se}, \mathrm{Cd}-\mathrm{Se}, \mathrm{Cd}-\mathrm{Mn}, \mathrm{Zn}-\mathrm{Cu}$, $\mathrm{Zn}-\mathrm{P}, \mathrm{Ca}-\mathrm{P}, \mathrm{Ca}-\mathrm{Mg}$, and $\mathrm{Mg}-\mathrm{P}$. The correlations between other elements within each of the analyzed breeds separately were also found.

Keywords Cow's milk · Breeds $\cdot$ Heavy metals $\cdot$ Trace elements $\cdot$ Correlations

\section{Introduction}

Milk as an excretion of the mammary gland can carry numerous xenobiotic substances, which constitute a technological risk factor for dairy products and, above all, for the health of the consumer. Determination of the residual concentrations of metals in milk could be an important "direct indicator" of the hygienic status of the milk, as well as an "indirect indicator" of the degree of pollution of the environment in which the milk was produced (Licata et al. 2004; GonzálezMontaña et al. 2012).

In the last few years, the contamination of milk is considered as one of the main dangerous aspects. Trace metals are a general collective term applying to the group of metals and metalloids with an atomic density greater than $6 \mathrm{~g} / \mathrm{cm}$. This term is widely recognized and usually applied to the elements such as cadmium $(\mathrm{Cd}), \mathrm{Cu}, \mathrm{Fe}$, lead $(\mathrm{Pb})$, and $\mathrm{Zn}$ which are commonly associated with pollution and toxicity 
problems (Malhat et al. 2012). One of the main problems with metals is their ability to bioaccumulate. Metal residues in milk are of particular concern because milk is largely consumed by infants and children (Tripathi et al. 1999).

The food chain is an important source of $\mathrm{Cd}$ and $\mathrm{Pb}$ accumulation, especially for plants grown on polluted soils. Significant amounts of $\mathrm{Cd}$ and $\mathrm{Pb}$ can be transferred from contaminated soil to plants and grass, causing accumulation of these potentially toxic metals in grazing ruminants, particularly in cattle (López Alonso et al. 2003; Miranda et al. 2005). Accumulation of $\mathrm{Cd}$ and $\mathrm{Pb}$ in ruminants causes toxic effects in cattle, but also in humans consuming meat and milk contaminated with toxic metals (González-Weller et al. 2006; Vromman et al. 2008; Cai et al. 2009).

$\mathrm{Cd}$ and $\mathrm{Pb}$ are amongst the elements that have caused the most concern in terms of adverse effects on human health. This is because they are readily transferred through food chains and are not known to serve any essential biological function. Lead is a pervasive and widely distributed environmental pollutant with no beneficial biological roles. The poisoning is more common in farm ruminants, which are considered most susceptible to the toxic effects of lead (Swarup et al. 2005). For that reason, the concentration of $\mathrm{Cd}$ and $\mathrm{Pb}$ in cow's milk should be monitored to ensure the consumers' health (Jen et al. 1994).

In most studies, the concentrations of toxic heavy metals and trace elements were determined in the milk obtained most frequently from Holstein-Friesian cows. It seems justified to compare the concentration and the relationships between the levels of individual elements in the milk of Simmental and Holstein-Friesian cows, kept in the same environment and fed identically, which allows finding breed differences in the concentration of elements and assimilability of heavy metals. Therefore, the aim of this study was the comparison of the concentrations of toxic heavy metals and trace elements in the milk of Simmental and HolsteinFriesian cows kept on an organic farm.

\section{Material and methods}

The research material comprised milk obtained from 20 Simmental dairy cows and 20 Holstein-Friesian cows kept on an organic farm with a total area of 4,000 ha of arable land including 3,000 ha of grassland, located in the northwestern part of the Lubuskie Province in Poland (Fig. 1). Approximately 1,000 ha is located in the "Mouth of Warta" National Park. The remaining area is a part of Natura 2000 land. Grasslands are situated in the basin of Odra and Warta Rivers. This farm, i.e., specializing in milk production, as the only one in this area maintained the Holstein-Friesian and Simmental cows under the same conditions, grazing them in the park area and its buffer zone.

The animals were kept in a loose barn with a free access to the stockyard located along the long walls of the building. Winter feeding of cows was based on the preserved feeds obtained from the farm (maize silage, wilted silage, ensilaged sugar beet pulp, hay, and concentrates), whereas during the summer feeding, cows additionally used the pasture.

Milk samples from a total of 40 cows (20 samples from each breed) at the amount of $50 \mathrm{~mL}$ from one cow were taken in September 2008. Each group, within the evaluated breed, consisted of cows of the similar milk yield $(3,800-4,000 \mathrm{~kg})$, similar age (3-7 years old), and similar lactation stage (100-150 day post-calving).

Elements $(\mathrm{Cd}, \mathrm{Pb}, \mathrm{Ca}, \mathrm{Mg}, \mathrm{P}, \mathrm{Cu}, \mathrm{Fe}, \mathrm{Mn}, \mathrm{Se}, \mathrm{Zn})$ were determined using inductively coupled plasma emission atomic spectrometry by means of an Optima 2000 DV instrument (PerkinElmer Inc.), after mineralization in a microwave system using the Anton Paar microwave oven. Measurements were made along the plasma in an axial direction. The analyzed elements were quantified using calibration curves plotted from analytical standards (Merck, Darmstadt, Germany). The limit of detection was as follows: $\mathrm{Cd} 0.1 \mu \mathrm{g} / \mathrm{L} ; \mathrm{Pb}, 1.0 \mu \mathrm{g} / \mathrm{L} ; \mathrm{Ca}$, $0.05 \mu \mathrm{g} / \mathrm{L} ; \mathrm{P}, 4 \mu \mathrm{g} / \mathrm{L} ; \mathrm{Mg}, 0.04 \mu \mathrm{g} / \mathrm{L} ; \mathrm{Cu}$, $0.4 \mu \mathrm{g} / \mathrm{L} ; \mathrm{Fe}, 0.1 \mu \mathrm{g} / \mathrm{L} ; \mathrm{Mn}, 0.1 \mu \mathrm{g} / \mathrm{L} ; \mathrm{Se}$, $4 \mu \mathrm{g} / \mathrm{L}$; and $\mathrm{Zn}, 0.2 \mu \mathrm{g} / \mathrm{L}$.

The correctness of the analytical procedure was tested by determining the analyzed elements in reference material Seronorm (Trace Elements Serum, Sero AS) $(n=3)$ together with the samples. The results agreed within $\pm 10 \%$ of the certified values. The analytical procedure was also checked by analysis of the blank samples. Blank digests $(n=4)$ were run with a series of milk samples, and no major interferences were found in the quantitative element analysis.

Statistical analysis of the data was performed using Statistica software (Statsoft Inc., version 10.0). Prior to analyses, data were investigated to determine their distribution using the Shapiro-Wilk $W$ test. The 


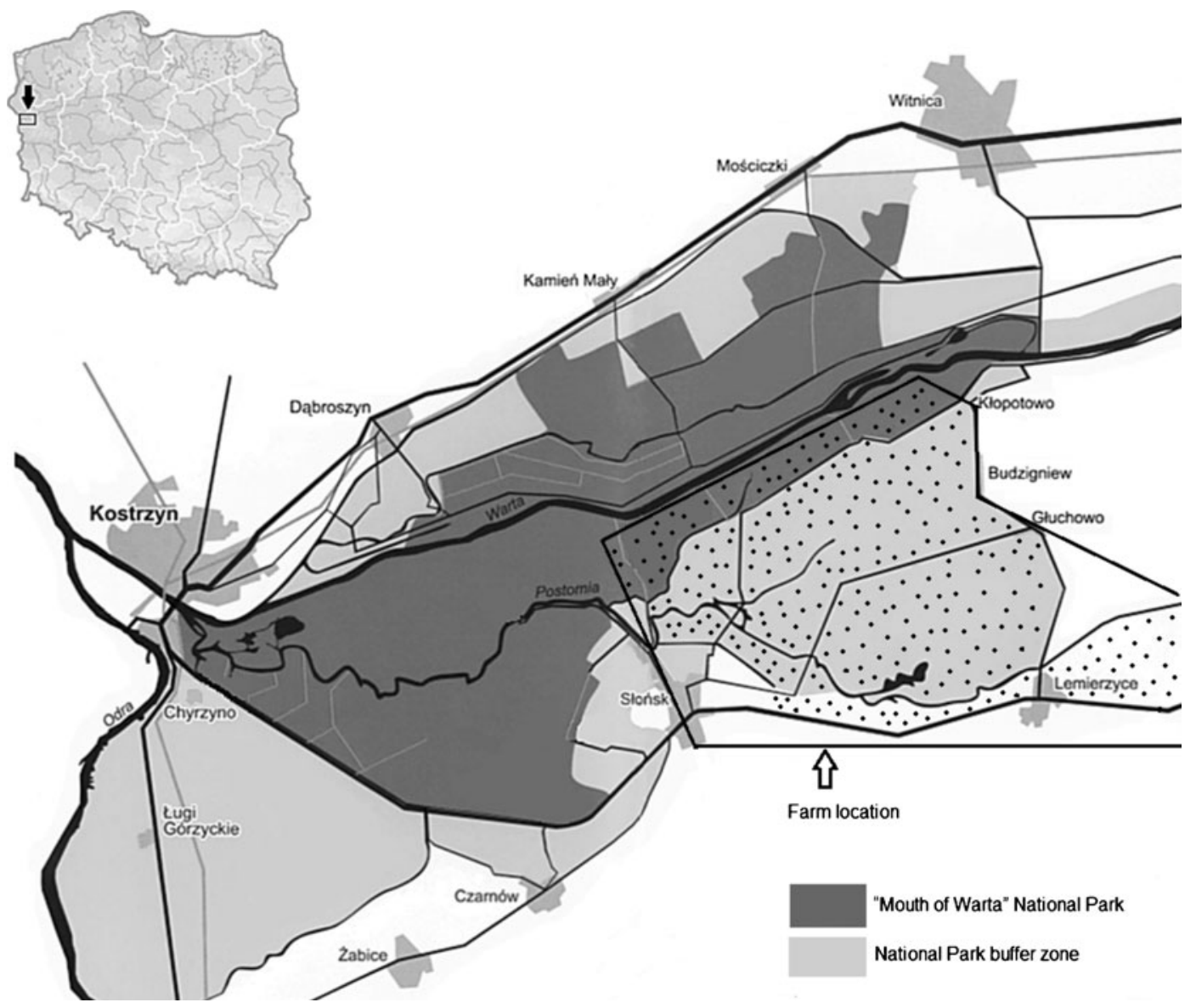

Fig. 1 Location of the province and the farm

concentrations of elements were log transformed to attain or approach a normal distribution of the data. Concentration of the analyzed elements in cow's milk between Simmental and Holstein-Friesian breeds was compared by the Student's $t$ test. Differences were considered significant at the level of $P<0.05, P<0.01$, and $P<0.001$. The relationships between the levels of individual elements in the milk of examined animals were calculated using Spearman rank correlation analysis. Statistical significance of coefficients of correlation was tested at the levels of $P<0.05, P<0.01$, and $P<$ 0.001 . All data are expressed throughout as an arithmetic mean, geometric mean, minimum values, maximum values, quartile deviation, and also standard error mean.

\section{Results and discussion}

The concentration of toxic heavy metals and trace elements in milk samples is given in Table 1. The milk of
Simmental cows had significantly lower concentration of $\mathrm{Pb}$ and $\mathrm{Cd}(P<0.001)$ and $\mathrm{Cu}(P<0.05)$ and significantly higher concentration of $\mathrm{Fe}$ and $\mathrm{Mg}(P<0.05)$ than did the milk of Holstein-Friesian cows. In the milk of Simmental cows, higher concentrations of $\mathrm{Mn}, \mathrm{Se}$, and $\mathrm{Ca}$ and lower concentrations of $\mathrm{Zn}$ and $\mathrm{P}$ were also found; however, these were not statistically significant differences.

Concentration of $\mathrm{Mg}, \mathrm{P}, \mathrm{Fe}, \mathrm{Mn}, \mathrm{Se}$, and $\mathrm{Zn}$ in the milk of cows of both breeds was within the standards proposed by Gaucheron (2005) and Hunt and Nielsen (2009), that of $\mathrm{Ca}$ was higher than the given range $1,043-1,283 \mu \mathrm{g} / \mathrm{mL}$, whereas that of $\mathrm{Cu}$ was at least $50 \%$ too low in relation to the suggested normal concentration of $0.1-0.35 \mu \mathrm{g} / \mathrm{mL}$. Unfortunately, the $\mathrm{Pb}$ content in the milk of cows of both breeds was two times higher than the permissible concentration of $0.02 \mu \mathrm{g} / \mathrm{mL}$ in the raw milk given by the standards of the European Commission Regulation (2006) establishing the highest permissible levels of some pollutants in foodstuffs. 


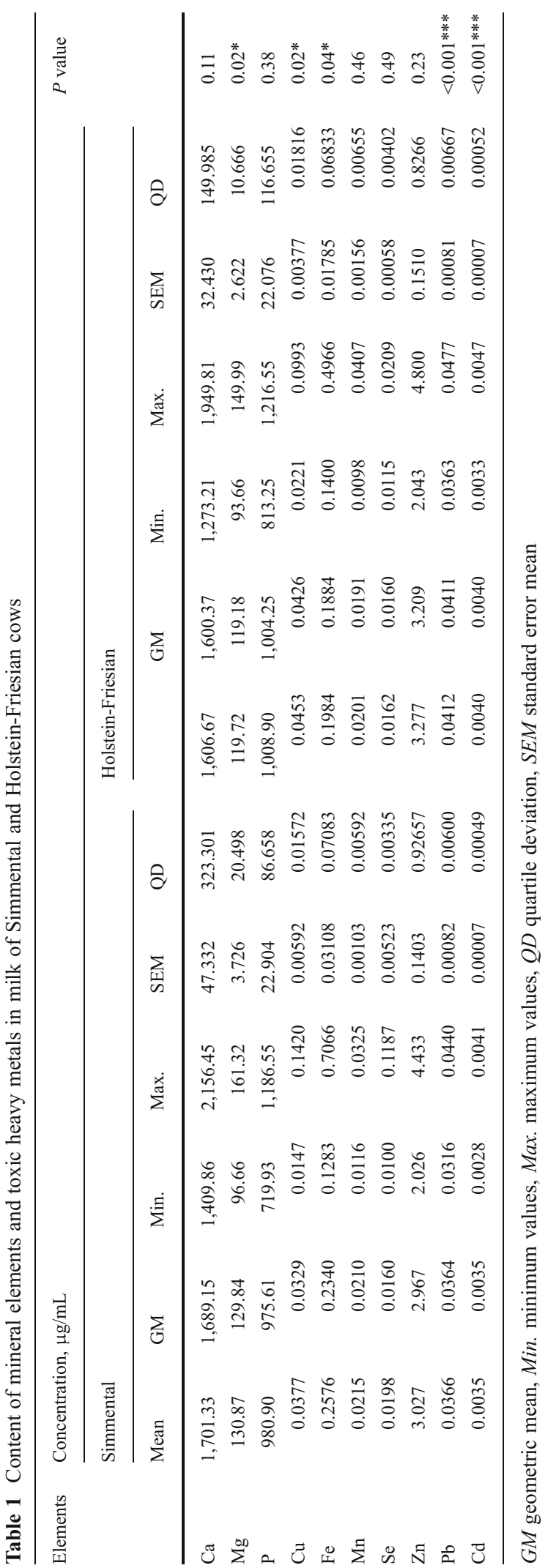

Differences in trace mineral metabolism between breeds of cattle have been reported. Fisher et al. (1970) conducted a study in which Ayrshires and Holsteins were treated identically. The magnesium and calcium content of the milk from Ayrshires was higher than that from Holsteins. In an experiment by Hermansen et al. (2005), a total of 480 samples of milk from 10 organically and 10 conventionally producing dairy farms in Denmark were analyzed for 45 trace elements and 6 major elements. The dairy cattle breeds were Danish-Holstein or Jersey. Compared with the Holsteins, Jerseys produced milk with higher concentrations of $\mathrm{Ba}, \mathrm{Ca}, \mathrm{Cu}, \mathrm{Fe}, \mathrm{Mg}, \mathrm{Mn}, \mathrm{Mo}, \mathrm{P}, \mathrm{Rh}$, and $\mathrm{Zn}$ and with a lower concentration of $\mathrm{Bi}$. In the study by Barłowska et al. (2006) on five Polish dairy cattle breeds (Simmental, Polish Red, Whitebacks, Polish Holstein-Friesian of Black-and-White and Red-and-White variety), the milk from Simmental cows was characterized by a significantly higher Fe, $\mathrm{Mg}$, and $\mathrm{Zn}$ content and a lower Mn content compared with the milk from Polish Holstein-Friesian cows of Black-and-White variety. It was found that the $\mathrm{Ca}$, $\mathrm{Mg}$, and $\mathrm{Zn}$ content was higher in the milk from Simmental, Polish Red, and Whiteback cows in comparison with Polish Holstein-Friesian cows of Blackand-White and Red-and-White varieties. The $\mathrm{Cu}$ content in the milk from Simmental cows was also very low (only $0.03 \mu \mathrm{g} / \mathrm{mL}$ ), two times lower than that in the milk from Polish Holstein-Friesian cows of Blackand-White and Red-and-White varieties as well as Polish Red cows $(0.06 \mu \mathrm{g} / \mathrm{mL})$ and three times lower compared with Polish Holstein-Friesians of Red-andWhite variety and Whitebacks $(0.09$ and $0.10 \mu \mathrm{g} / \mathrm{mL}$, respectively).

In the milk of Simmental and Holstein-Friesian cows from the organic farm, particularly low $\mathrm{Cu}$ concentrations amounting to 0.0377 and $0.0453 \mu \mathrm{g} / \mathrm{mL}$, respectively, were recorded, indicating the deficiency of this element in animals and thus in environment and feed either. Copper deficiency is a common nutritional problem in ruminants, though $\mathrm{Cu}$ excess is also commonly encountered, especially in sheep. It is considered that $\mathrm{Cu}$ concentrations between 0.1 and $0.9 \mu \mathrm{g} / \mathrm{mL}$ are the "normal" range in milk (Bilandžić et al. 2011).

Breed effects for efficiency in metabolizing $\mathrm{Cu}$ are well documented (Smart and Christensen 1985; Littledike et al. 1995; Ward et al. 1995; Du et al. 1996). In an experiment by Du et al. (1996), Holstein 
and Jersey primiparous cows and growing heifers were supplemented with either 5 or $80 \mathrm{mg}$ of copper per kilogram dry matter. At the end of the 60-day experiment, the hepatic $\mathrm{Cu}$ concentration, plasma $\mathrm{Cu}$ concentration, and ceruloplasmin oxidase activity clearly showed a genetic difference in $\mathrm{Cu}$ absorption and post-absorption metabolism between Holstein and Jersey breeds. Jerseys had higher liver copper concentrations relative to Holsteins across both treatments. Furthermore, liver copper concentrations increased more rapidly and were higher in the Jerseys compared to Holsteins supplemented with $80 \mathrm{mg}$ of copper per kilogram dry matter. Overall serum ceruloplasmin oxidase activity was higher in Jerseys than Holsteins. Additionally, Jersey cows and heifers had higher liver $\mathrm{Fe}$ and lower liver $\mathrm{Zn}$ concentrations than did Holstein cows and heifers at the end of the experiment. No differences in plasma $\mathrm{Fe}$ and $\mathrm{Zn}$ appeared between breeds. These data indicate that Jerseys and Holsteins metabolize $\mathrm{Cu}, \mathrm{Zn}$, and $\mathrm{Fe}$ differently.

The genetic difference may be related to the efficiency of dietary $\mathrm{Cu}$ absorption, the excretion of endogenous $\mathrm{Cu}$, or the amount of feed intake. Gooneratne et al. (1994) suggested that the differences in endogenous $\mathrm{Cu}$ excretion also contributed to the genetic differences in the retention of hepatic $\mathrm{Cu}$.

$\mathrm{Cu}$ deficiency occurs more frequently in Simmental than in other breeds of cattle (Gooneratne et al. 1994; Ward et al. 1995; Mullis et al. 2003). Bile Cu concentration and bile $\mathrm{Cu}$ excretion were higher in Simmental cattle than in Angus cattle (Gooneratne et al. 1994). Ward et al. (1995) conducted a study in which Angus and Simmental steers were placed in metabolism crates to monitor apparent absorption and retention of copper. At the end of the experiment, plasma copper concentrations, apparent absorption, and retention of copper were higher in Angus steers. The authors indicate that Simmental cattle may have a higher copper requirement than Angus cattle and that these different requirements may be related to the differences in copper absorption from the gastrointestinal tract between breeds. Furthermore, it has also been suggested that these breed differences in copper metabolism may not be due solely to differences in absorption, but also to the manner in which copper is utilized or metabolized post-absorption. Simmental steers had also lower serum and liver $\mathrm{Cu}$ concentrations and serum ceruloplasmin activity than Angus throughout the study by Mullis et al. (2003). Smart and Christensen (1985) reported that Hereford-sired cows had greater plasma $\mathrm{Cu}$ concentrations during gestation than did Simmental-sired cows.

Others have reported differences in serum $\mathrm{Mg}, \mathrm{Ca}$, and P. Wiener (1980) found a difference in blood $\mathrm{Cu}$, $\mathrm{Ca}, \mathrm{P}$, and $\mathrm{Mg}$ concentrations between Friesian and Jersey cattle. Angus had higher serum $\mathrm{Mg}$ than did Hereford cows in a study by Greene et al. (1989) and true digestibility of $\mathrm{Mg}$ in Angus cows of this herd was higher than that of Hereford. However, Chirase et al. (1988) found that serum $\mathrm{Mg}, \mathrm{Ca}$, and $\mathrm{P}$ were similar in Angus, Angus $\times$ Hereford, Angus $\times$ Jersey, Brahman $\times$ Hereford, Brahman $\times$ Jersey, and Hereford $\times$ Jersey cows grazing oat pastures.

Littledike et al. (1995) compared the mineral status of Angus, Braunvieh, Charolais, Gelbvieh, Hereford, Limousin, Red Poll, Pinzgauer, and Simmental breeds consuming similar diets. In adult cattle, liver $\mathrm{Cu}$ was higher for the Limousin breed than for all others, except for Angus. Liver Zn concentrations were higher for Limousin than for Pinzgauer, but no other breed differences were observed. Serum Ca concentrations were higher for Angus, Red Poll, and Limousin than for Simmental, and Red Poll had higher concentrations of serum $\mathrm{Ca}$ than did Braunvieh. Serum $\mathrm{Mg}$ concentrations were higher for Angus than for Hereford. Concentrations of serum $\mathrm{Ca}$ were positively correlated with serum concentrations of $\mathrm{Cu}, \mathrm{Zn}$, and $\mathrm{Mg}$, but negatively correlated with liver Fe.

In few studies, an effect of breed on the efficiency of Se metabolism was also shown. In an experiment by Sprinkle et al. (2006), Brahman cross (Brahman $\times$ Salers or Brahman $\times$ Hereford) cows were more efficient in metabolizing Se, having greater whole blood Se than either composite cows (25\% Hereford, Angus, Gelbevieh, and Senepol or Barzona) or Hereford cows. Langlands et al. (1980) reported that Brahman cattle in Australia had greater blood Se than Brahman cross, Africander, Africander cross, Brahman-Africander $\times$ Hereford-Shorthorn cross, or Hereford $\times$ Shorthorn cross cattle. In evaluating specific sire breeds, they also reported that Brahman $\times$ Hereford crosses had greater Se than Hereford $\times$ Hereford, Friesan $\times$ Hereford, and Simmental $\times$ Hereford genotypes.

$\mathrm{Cd}$ and $\mathrm{Pb}$ are environmental pollutants toxic to humans and animals (Cai et al. 2009). $\mathrm{Cd}$ and $\mathrm{Pb}$ are nonbiodegradable, and their accumulation in the environment raises agricultural and public health concerns (Olsson et al. 2005; De Vries et al. 2007). In our study, 
$\mathrm{Pb}$ and $\mathrm{Cd}$ concentrations in the milk of Simmental cows were significantly lower $(P<0.001)$ compared to Holstein-Frisian cows. The $\mathrm{Pb}$ concentration in the milk of both breeds exceeded, however, permissible EU standards, amounting to 0.0366 and $0.0412 \mu \mathrm{g} / \mathrm{mL}$ for Simmental and Holstein-Friesian cows, respectively. In the study by Gabryszuk et al. (2010), the Pb concentration in the milk of cows from organic farms was much lower and ranged from 0.0041 to $0.0062 \mu \mathrm{g} / \mathrm{mL}$.

Heavy metal contamination in milk has been reported also in different countries and regions (Simsek et al. 2000; Licata et al. 2004; Pavlovic et al. 2004). In the study by Bilandžić et al. (2011), mean lead concentrations exceeded the maximum residue levels in the north and the south regions of Croatia (0.0587 and $0.0362 \mu \mathrm{g} / \mathrm{mL}$, respectively). Levels above $0.020 \mu \mathrm{g} / \mathrm{mL}$ were measured in $35.5 \%$ of samples from the north and $28.3 \%$ of samples from the south regions. In the study by Pavlovic et al. (2004), the $\mathrm{Pb}$ level ranged from 0.028 to $0.036 \mu \mathrm{g} / \mathrm{mL}$, but that of $\mathrm{Cd}$ was between 0.005 and $0.006 \mu \mathrm{g} / \mathrm{mL}$ for a majority of 15 farms in Croatia. Sikrić et al. (2003) reported even higher $\mathrm{Pb}$ concentration in milk, which amounted to $0.023-0.070 \mu \mathrm{g} / \mathrm{mL}$.

The interesting aspect in the present study is the interaction between toxic heavy metals $(\mathrm{Pb}$ and $\mathrm{Cd})$ and major nutritional and trace elements $(\mathrm{Ca}, \mathrm{Mg}, \mathrm{P}$, $\mathrm{Cu}, \mathrm{Fe}, \mathrm{Mn}, \mathrm{Se}, \mathrm{Zn}$ ) in milk because the nutritional function of milk is important for health. In the liver or kidney, the interactions of $\mathrm{Zn}, \mathrm{Cu}, \mathrm{Se}, \mathrm{Fe}, \mathrm{Ca}$, and $\mathrm{Pb}$ or $\mathrm{Cd}$ are well known from the earlier literature, but their relation in milk is not clearly reported (Isaac et al. 2012).

In the milk of Simmental and Holstein-Friesian cows, significant very high or high positive correlations (Table 2) were found between the concentrations: $\mathrm{Pb}-$ $\mathrm{Cd}(r=0.86$ vs. $r=0.87), \mathrm{Pb}-\mathrm{Se}(r=0.68$ vs. $r=0.83)$, $\mathrm{Cd}-\mathrm{Se}(r=0.62$ vs. $r=0.70), \mathrm{Cd}-\mathrm{Mn}(r=0.49$ vs. $r=0.61), \mathrm{Zn}-\mathrm{Cu}(r=0.57$ vs. $r=0.46), \mathrm{Zn}-\mathrm{P} \quad(r=0.46$ vs. $r=0.57), \mathrm{Ca}-\mathrm{P}(r=0.64$ vs. $r=0.81), \mathrm{Mg}-\mathrm{P}(r=0.55$ vs. $r=0.66)$, and $\mathrm{Ca}-\mathrm{Mg}(r=0.89$ vs. $r=0.62)$.

Moreover, in the milk of Simmental cows, statistically significant correlations were observed between milk concentrations of: $\mathrm{Cd}$ and $\mathrm{Mg}(r=-0.46), \mathrm{Pb}$ and $\mathrm{Ca}(r=-0.41)$, and $\mathrm{Pb}$ and $\mathrm{Fe}(r=0.57)$. In the milk of Holstein-Friesian cows, the concentration of $\mathrm{Pb}$ and $\mathrm{Cd}$ was positively and significantly correlated with $\mathrm{P}$ $(r=0.47$ and $r=0.49$, respectively), Mn ( $r=0.57$ and $r=0.67$, respectively), Se ( $r=0.83$ and $r=0.70$, respectively), and $\mathrm{Zn}(r=0.49$ and $r=0.55$ respectively). In addition, $\mathrm{Mn}$ concentration significantly correlated with $\mathrm{Ca}(r=0.55), \mathrm{P}(r=0.65)$, Se $(r=0.48)$, and $\mathrm{Zn}$ $(r=0.58)$, concentration of $\mathrm{Zn}$ with $\mathrm{Cu}(r=0.57)$ and $\mathrm{P}$ $(r=0.57)$, and concentration of Se with P $(r=0.54)$.

A very high, significant, and positive correlation between $\mathrm{Ca}$ and $\mathrm{Mg}(r=0.873)$ in the milk of cows was reported also by Rodríguez Rodríguez et al. (1999). However, contrary to our results, they found significant negative correlations between $\mathrm{Cu}$ and $\mathrm{Zn}(r=-0.377)$ and not high positive correlations between $\mathrm{Fe}$ and $\mathrm{Cu}$ as well as $\mathrm{Fe}$ and $\mathrm{Zn}$. In the study by Sikrić et al. (2003), the $\mathrm{Cu}$ concentration in milk was significantly positively correlated with the concentrations of $\mathrm{Fe}(r=0.613)$ and $\mathrm{Zn}(r=$ $0.629)$ and that of $\mathrm{Zn}$ with $\mathrm{Mn}(r=0.731)$, which was proved in our work. In the milk of both analyzed breeds, the $\mathrm{Pb}$ concentration was very highly correlated with $\mathrm{Cd}$ concentration ( $r=0.85$ vs. $r=0.87$ ), whereas in the study by Pavlovic et al. (2004) no correlation between these metals was found. Stawarz et al. (2007) reported strong positive correlations between $\mathrm{Cd}$ and $\mathrm{Ca}(r=0.220), \mathrm{Cd}$ and $\mathrm{Mg}(r=0.201), \mathrm{Cd}$ and $\mathrm{Zn}(r=0.279)$, and $\mathrm{Cu}$ and $\mathrm{Ca}$ $(r=0.347)$ and negative correlation between $\mathrm{Pb}$ and $\mathrm{Ca}$ $(r=-0.295)$ in breast milk.

There is a paucity of earlier literature, particularly concerning animals, to compare the present finding. The correlations between the elements of milk were rarely analyzed (Rodríguez Rodríguez et al. 1999). The available literature describes relationships between different elements, principally in the liver, kidneys, and muscles of animals (López Alonso et al. 2002, 2004; Blanco-Penedo et al. 2006), in the limited number in blood or serum (López Alonso et al. 2002). The largest number of significant correlations between toxic and essential elements is found in the kidneys followed by liver (Tomza-Marciniak et al. 2011), which according to Lopez Alonso et al. (2004) is a reflection that these organs play the main role in trace element metabolism.

Experimental exposure of rats to either lead or cadmium or both concomitantly has been demonstrated to influence the metabolism and tissue concentration of divalent cations like zinc, copper, and iron and tissuespecific changes in the distribution of iron, zinc, copper, cobalt, and manganese have been documented after experimental administration of lead and cadmium in cattle and rats (Patra and Swarup 1998; Oishi et al. 2000; Patra et al. 2001, 2008).

During lactation, $\mathrm{Pb}$ and $\mathrm{Cd}$ are thought to be transported from maternal plasma to mammary gland and secreted into milk along with $\mathrm{Cu}$ and $\mathrm{Zn}$. 
Table 2 Spearman rank correlations between milk concentration of different mineral elements

\begin{tabular}{|c|c|c|c|c|c|c|c|c|c|}
\hline Elements & $\mathrm{Mg}$ & $\mathrm{P}$ & $\mathrm{Cu}$ & $\mathrm{Fe}$ & $\mathrm{Mn}$ & $\mathrm{Se}$ & $\mathrm{Zn}$ & $\mathrm{Pb}$ & $\mathrm{Cd}$ \\
\hline \multicolumn{10}{|c|}{ Simmental } \\
\hline $\mathrm{Ca}$ & $0.89 * * *$ & $0.64 * *$ & 0.22 & -0.26 & 0.08 & -0.22 & 0.38 & $-0.41 *$ & -0.36 \\
\hline $\mathrm{Mg}$ & & $0.55^{*}$ & 0.13 & -0.13 & -0.08 & -0.26 & 0.36 & -0.40 & $-0.46^{*}$ \\
\hline $\mathrm{P}$ & & & 0.28 & -0.32 & -0.20 & -0.09 & $0.46^{*}$ & -0.32 & -0.29 \\
\hline $\mathrm{Cu}$ & & & & 0.29 & 0.19 & 0.13 & $0.57 * *$ & 0.06 & 0.03 \\
\hline $\mathrm{Fe}$ & & & & & 0.24 & 0.42 & 0.03 & $0.57 * *$ & 0.28 \\
\hline $\mathrm{Mn}$ & & & & & & 0.42 & 0.15 & 0.43 & $0.49 *$ \\
\hline $\mathrm{Se}$ & & & & & & & -0.10 & $0.68 * *$ & $0.62 * *$ \\
\hline $\mathrm{Zn}$ & & & & & & & & -0.30 & -0.35 \\
\hline $\mathrm{Pb}$ & & & & & & & & & $0.86 * * *$ \\
\hline \multicolumn{10}{|c|}{ Holstein-Friesian } \\
\hline $\mathrm{Ca}$ & $0.62 * *$ & $0.81 * * *$ & 0.26 & 0.28 & $0.55^{*}$ & 0.33 & 0.35 & 0.17 & 0.17 \\
\hline $\mathrm{Mg}$ & & $0.66^{* *}$ & 0.09 & 0.24 & 0.37 & 0.17 & 0.37 & 0.27 & 0.27 \\
\hline $\mathrm{P}$ & & & 0.20 & 0.40 & $0.65 * *$ & $0.54 *$ & $0.57 * *$ & $0.47 *$ & $0.49^{*}$ \\
\hline $\mathrm{Cu}$ & & & & 0.25 & 0.39 & 0.12 & $0.46^{*}$ & 0.24 & 0.15 \\
\hline $\mathrm{Fe}$ & & & & & 0.33 & -0.14 & 0.35 & -0.02 & 0.05 \\
\hline $\mathrm{Mn}$ & & & & & & $0.48^{*}$ & $0.58 * *$ & $0.57 * *$ & $0.61 * *$ \\
\hline $\mathrm{Se}$ & & & & & & & 0.33 & $0.83 * * *$ & $0.70^{* *}$ \\
\hline $\mathrm{Zn}$ & & & & & & & & $0.49 *$ & $0.55^{*}$ \\
\hline $\mathrm{Pb}$ & & & & & & & & & $0.87 * * *$ \\
\hline
\end{tabular}

$* * * P<0.001, * * P<0.01, * P<0.05$, statistically significant coefficient of correlation

However, the interaction between toxic heavy metals and trace elements (Ca, Mg, P, Cu, Fe, Mn, Se, Zn) has not been understood clearly, particularly in milk. There is a good level of understanding of the role of major nutritional elements like $\mathrm{Ca}, \mathrm{Mg}, \mathrm{P}, \mathrm{Na}$, and $\mathrm{K}$ in milk, but the effects of $\mathrm{Pb}$ and $\mathrm{Cd}$ on their metabolism have not been sufficiently investigated (Isaac et al. 2012).

$\mathrm{Cd}$ and $\mathrm{Pb}$ mainly distribute in the liver and kidney, where $\mathrm{Cd}$ is bound to metallothionein (MT), a small, cysteine-rich metal-binding protein (Klaassen et al. 1999).

Several studies have suggested that interactions between $\mathrm{Cd}$ or $\mathrm{Pb}$ and $\mathrm{Zn}$ in the organism result in a high degree from an affinity of both metals to MT and their ability to induce its synthesis. They can induce MT synthesis in various tissues, especially in the intestine, liver, and kidney (Brzóska and MoniuszkoJakoniuk 2001; Cai et al. 2009). Metallothionein, which is synthesized in response to cadmium, lead, zinc, copper, or mercury exposure (MT inducers), contributes to the accumulation of metals by eliminating them from metabolism. Olsson et al. (2010) found a significant relationship between kidney levels of $\mathrm{Cd}$ and metallothionein. Another way of eliminating metals from metabolism is through the formation of neutral complexes (e.g., $\mathrm{Se}-\mathrm{Cd}$ and $\mathrm{Se}-\mathrm{Pb}$ ) by selenium, which are then bound by proteins similar to metallothionein. This is possible because of the high affinity of selenium for these elements (Nehru and Iyer 1994; Tomza-Marciniak et al. 2011). The interaction between $\mathrm{Zn}$ and $\mathrm{Cu}$ has been extensively reported (Blanco-Penedo et al. 2006; Bremner and Beattie 1995) and is a consequence of the ability of these metals to induce synthesis of metallothioneins and of their competition for metallothionein-binding sites.

Interaction between toxic heavy metals $(\mathrm{Pb}$ and $\mathrm{Cd})$ and major nutritional and trace elements was also found in humans, most frequently in blood and serum (Bárány et al. 2002) and in the milk of nursing mothers (Perrone et al. 1994; Krachler et al. 1998; Stawarz et al. 2007). Wang et al. (2012) reported 
correlations among the toxic $(\mathrm{Cd}, \mathrm{Pb})$ and nutritionally essential ( $\mathrm{Zn}, \mathrm{Cu}, \mathrm{Fe}, \mathrm{Mn}, \mathrm{Se}$ ) elements in the blood, also urine and feces in the male. In the case of the toxic metals, a significant positive correlation was found for $\mathrm{Cd}-\mathrm{Pb}$ in blood and a moderate correlation in urine. Cd was positively correlated with most of the essential elements in both urinary and fecal excretion. Moreover, significant direct correlations were found between $\mathrm{Cd}$ and either $\mathrm{Zn}$ or Se concentration in both urine and feces, whereas a significant negative correlation was found between $\mathrm{Cd}$ and $\mathrm{Se}$ in blood.

At present, we have no biological explanations to several others of the reported correlations and more studies are needed in this area.

Correlation analysis also showed some differences among the analyzed cow breeds. The correlations between $\mathrm{Pb}$ and $\mathrm{Zn}$ as well as $\mathrm{Cd}$ and $\mathrm{Zn}$ are noteworthy. In the milk from Holstein-Friesians (HF) cows, very high positive and significant correlations between these elements were recorded $(0.83$ and 0.70 , respectively), whereas in the milk from Simmental cows, these correlations were negative, weak, and statistically nonsignificant $(-0.30$ and -0.35 , respectively). In Simmental cows, negative correlations were also found between $\mathrm{Pb}$ and $\mathrm{Cd}$ and $\mathrm{Ca}, \mathrm{Mg}$, and $\mathrm{P}$; however, only those between $\mathrm{Pb}$ and $\mathrm{Ca}(-0.41)$ and $\mathrm{Cd}$ and $\mathrm{Mg}(-0.46)$ were significant. In HF cows, only correlations between these elements and $\mathrm{P}$ were positive and significant $(0.47$ and 0.49 for $\mathrm{Pb}-\mathrm{P}$ and $\mathrm{Cd}-\mathrm{P}$, respectively). A high positive and significant correlation between $\mathrm{Pb}$ and Fe was also observed in Simmental cows, whereas it was low in HF cows. In the milk from HF cows, high positive and significant correlations between $\mathrm{Mn}$ and $\mathrm{Ca}, \mathrm{P}, \mathrm{Se}, \mathrm{Zn}$, and $\mathrm{Pb}$ as well as between Se and $\mathrm{P}$ were additionally found, whereas in Simmental cows, these correlations were nonsignificant and the obtained correlation coefficients much smaller. These correlations confirm differences in trace mineral metabolism between the studied breeds.

\section{Conclusions}

The present research showed that the milk of Simmental cows had more favorable mineral composition and lower concentration of toxic heavy metals compared to the milk of Holstein-Friesian cows. In the milk of Simmental cows, significantly lower concentrations of $\mathrm{Pb}, \mathrm{Cd}$, and $\mathrm{Cu}$, significantly higher concentrations of $\mathrm{Fe}$ and
$\mathrm{Mg}$, as well as nonsignificantly higher concentrations of $\mathrm{Ca}, \mathrm{Mn}$, and Se were found. In the milk of both breeds, particularly low $\mathrm{Cu}$ concentrations (0.0377 vs. $0.0453 \mu \mathrm{g} / \mathrm{mL}$ ), at least two times lower than the recommended standards, were recorded, which indicates the deficiency of this element in animals as well as in environment and feed. Also, the $\mathrm{Pb}$ concentration in milk that was higher than the recommended standards was found. Simmental and Holstein-Friesian cows remained in the same environment and were identically fed, which allows us to suppose that the differences obtained between these breeds in the content of the examined elements and heavy metals in milk are caused by differences of metabolic background.

Open Access This article is distributed under the terms of the Creative Commons Attribution License which permits any use, distribution, and reproduction in any medium, provided the original author(s) and the source are credited.

\section{References}

Bárány, E., Bergdahl, I. A., Bratteby, L. E., Lundh, T., Samuelson, G., Schütz, A., et al. (2002). Relationships between trace element concentrations in human blood and serum. Toxicology Letters, 134(1-3), 177-184.

Barłowska, J., Litwińczuk, Z., Król, J., \& Kędzierska-Matysek, M. (2006). Fatty acid profile and minerals content in milk from cows of various breeds over spring-summer feeding period. Polish Journal of Food and Nutrition Sciences, 56(1s), 13-16.

Bilandžić, N., Dokić, M., Sedak, M., Božica, S., Varenina, I., Knežević, Z., et al. (2011). Trace element levels in raw milk from northern and southern regions of Croatia. Food Chemistry, 127(1), 63-66.

Blanco-Penedo, I., Cruz, J. M., López-Alonso, M., Miranda, M., Castillo, C., Hernández, J., et al. (2006). Influence of copper status on the accumulation of toxic and essential metals in cattle. Environment International, 32(7), 901906.

Bremner, I., \& Beattie, J. H. (1995). Copper and zinc metabolism in health and disease: speciation and interactions. Proceedings of the Nutrition Society, 54(2), 489-499.

Brzóska, M. M., \& Moniuszko-Jakoniuk, J. (2001). Interactions between cadmium and zinc in the organism. Food and Chemical Toxicology, 39(10), 967-980.

Cai, Q., Long, M. L., Zhu, M., Zhou, Q. Z., Zhang, L., \& Liu, J. (2009). Food chain transfer of cadmium and lead to cattle in a lead-zinc smelter in Guizhou, China. Environmental Pollution, 157(11), 3078-3082.

Chirase, N. K., Greene, L. W., Lunt, D. K., Baker, J. F., \& Knutson, R. E. (1988). Serum and ruminal fluid characteristics of beef cows grazing oat pastures and supplemented with or without lasalocid. Journal of Animal Science, 66(7), 17461754. 
de Vries, W., Römkens, P. F., \& Schütze, G. (2007). Critical soil concentrations of cadmium, lead, and mercury in view of health effects on humans and animals. Reviews of Environmental Contamination and Toxicology, 191, 91-130.

Du, Z., Hemkin, R. W., \& Harmon, R. J. (1996). Copper metabolism of Holstein and Jersey cows and heifers fed diets high in cupric sulfate or copper proteinate. Journal of Dairy Science, 79(10), 1873-1880.

EC. (2006). Commission regulation (EC) no. 1881/2006 of 19 December 2006 setting maximum levels for certain contaminants in foodstuffs. Official Journal of the European Union, L364, 5-24.

Fisher, L. J., Macintosff, A. I., \& Carson, R. B. (1970). Effects of ad libitum versus restricted intake of concentrate and stage of lactation on the mineral content of cow's milk. Canadian Journal of Animal Science, 50(1), 121-127.

Gabryszuk, M., Słoniewski, K., Metera, E., \& Sakowski, T. (2010). Content of mineral elements in milk and hair of cows from organic farms. Journal of Elementology, 15(2), 259-267.

Gaucheron, F. (2005). The minerals of milk. Reproduction Nutrition Development, 45(4), 473-483.

González-Montaña, J. R., Senís, E., Gutiérrez, A., \& Prieto, F. (2012). Cadmium and lead in bovine milk in the mining area of the Caudal River (Spain). Environmental Monitoring and Assessment, 184(7), 4029-4034.

González-Weller, D., Karlsson, L., Caballero, A., Hernández, F., Gutiérrez, A., González-Iglesias, T., et al. (2006). Lead and cadmium in meat and meat products consumed by the population in Tenerife Island, Spain. Food Additives and Contaminants, 23(8), 757-763.

Gooneratne, S. R., Symonds, H. W., Bailey, J. V., \& Christensen, D. A. (1994). Effects of dietary copper, molybdenum, and sulfur on biliary copper and zinc excretion in Simmental and Angus cattle. Canadian Journal of Animal Science, 74(2), 315-325.

Greene, L. W., Baker, J. F., \& Hardt, P. F. (1989). Use of animal breeds and breeding to overcome the incidence of grass tetany: a review. Journal of Animal Science, 67(12), 34633469 .

Hermansen, J. E., Badsberg, J. H., Kristensen, T., \& Gundersen, V. (2005). Major and trace elements in organically or conventionally produced milk. The Journal of Dairy Research, 72(3), 362-368.

Hunt, C. D., \& Nielsen, F. H. (2009). Nutritional aspects of minerals in bovine and human milks. In P. L. H. McSweeney \& P. F. Fox (Eds.), Advanced dairy chemistry volume 3: lactose, water, salts and minor constituents (pp. 392-398). Heidelberg: Springer. doi:10.1007/978-0387-84865-5_10.

Isaac, C. P., Sivakumar, A., \& Kumar, C. R. (2012). Lead levels in breast milk, blood plasma and intelligence quotient: a health hazard for women and infants. Bulletin of Environmental Contamination and Toxicology, 88(2), 145-149.

Jen, S. L., Lee, S. J., \& Lin, S. Y. (1994). Determination of cadmium and lead in raw milk by graphite furnace atomic absorption spectrophotometer. Journal of Dairy Science, 77(4), 945-949.

Klaassen, C. D., Liu, J., \& Choudhuri, S. (1999). Metallothionein: an intracellular protein to protect against cadmium toxicity. Annual Review of Pharmacology, 39(1), 267-294.
Krachler, M., Li, F. S., Rossipal, E., \& Irgolic, K. J. (1998). Changes in the concentrations of trace elements in human milk during lactation. Journal of Trace Elements in Medicine and Biology, 12(3), 159-176.

Langlands, J. P., Bowles, J. E., Donald, G. E., Ch'ang, T. S., Evans, R., Hearnshaw, H., et al. (1980). Genotype as a source of variation in selenium concentration and glutathione peroxidase activity of whole blood from grazing sheep and cattle. Australian Journal of Agricultural Research, 31 (4), 839-848.

Licata, P., Trombetta, D., Cristani, M., Giofrè, F., Martino, D., Calò, M., et al. (2004). Levels of "toxic" and "essential" metals in samples of bovine milk from various dairy farms in Calabria, Italy. Environment International, 30(1), 1-6.

Littledike, E. T., Wittum, T. E., \& Jenkins, T. G. (1995). Effect of breed, intake, and carcass composition on the status of several macro and trace minerals of adult beef cattle. Journal of Animal Science, 73(7), 2113-2119.

López Alonso, M., Benedito, J. L., Miranda, M., Castillo, C., Hernández, J., \& Shore, R. F. (2002). Interactions between toxic and essential trace metals in cattle from a region with low levels of pollution. Archives of Environmental Contamination and Toxicology, 42(2), 165-172.

López Alonso, M., Prieto Montaña, F., Miranda, M., Castillo, C., Hernández, J., \& Benedito, J. L. (2003). Cadmium and lead accumulation in cattle in NW Spain. Veterinary and Human Toxicology, 45(3), 128-130.

López Alonso, M., Prieto Montaña, F., Miranda, M., Castillo, C., Hernández, J., \& Luis Benedito, J. (2004). Interactions between toxic ( $\mathrm{As}, \mathrm{Cd}, \mathrm{Hg}$ and $\mathrm{Pb}$ ) and nutritional essential ( $\mathrm{Ca}, \mathrm{Co}, \mathrm{Cr}, \mathrm{Cu}, \mathrm{Fe}, \mathrm{Mn}, \mathrm{Mo}, \mathrm{Ni}, \mathrm{Se}, \mathrm{Zn}$ ) elements in the tissues of cattle from NW Spain. BioMetals, 17(4), 389397.

Malhat, F., Hagag, M., Saber, A., \& Fayz, A. E. (2012). Contamination of cows milk by heavy metal in Egypt. Bulletin of Environmental Contamination and Toxicology, 88 (4), 611-613.

Miranda, M., López Alonso, M., Castillo, C., Hernández, J., \& Benedito, J. L. (2005). Effects of moderate pollution on toxic and trace metal levels in calves from a polluted area of northern Spain. Environment International, 31(4), 543-548.

Mullis, L. A., Spears, J. W., \& McCraw, R. L. (2003). Effects of breed (Angus vs Simmental) and copper and zinc source on mineral status of steers fed high dietary iron. Journal of Animal Science, 81(1), 318-322.

Nehru, B., \& Iyer, A. (1994). Effect of selenium on lead-induced neurotoxicity in different brain regions of adult rats. Journal of Environmental Pathology, Toxicology and Oncology, 13 (4), 265-268.

Oishi, S., Nakagawa, J. I., \& Ando, M. (2000). Effect of cadmium administration on the endogenous metal balance in rats. Biological Trace Element Research, 76(3), 257-278.

Olsson, I. M., Eriksson, J., Oborn, I., Skerfving, S., \& Oskarsson, A. (2005). Cadmium in food production systems: a health risk for sensitive population groups. Ambio, 34(4-5), 344-351.

Olsson, I. M., Jonsson, S., \& Oskarsson, A. (2010). Cadmium and zinc in kidney, liver, muscle and mammary tissue from dairy cows in conventional and organic farming. Journal of Environmental Monitoring, 3(5), 531-538. 
Patra, R. C., \& Swarup, D. (1998). Effect of long term exposure of cadmium on level of zinc in rat tissues. Indian Journal of Veterinary Research, 7, 47-49.

Patra, R. C., Swarup, D., Dwivedi, S. K., \& Sahoo, A. (2001). Trace minerals in blood of young calves during exposure to lead. Indian Journal of Animal Science, 71(6), 507-510.

Patra, R. C., Swarup, D., Kumar, P., Nandi, D., Naresh, R., \& Ali, S. L. (2008). Milk trace elements in lactating cows environmentally exposed to higher level of lead and cadmium around different industrial units. Science of the Total Environment, 404(1), 36-43.

Pavlovic, I., Sikiric, M., Havranek, J. L., Plavljanic, N., \& Brajenovic, N. (2004). Lead and cadmium levels in raw cow's milk from an industrialised Croatian region determined by electrothermal atomic absorption spectrometry. Czech Journal of Animal Science, 49(4), 164-168.

Perrone, L., Di Palma, L., Di Toro, R., Gialanella, G., \& Moro, R. (1994). Interaction of trace elements in a longitudinal study of human milk from full-term and preterm mothers. Biological Trace Element Research, 41(3), 321-330.

Rodríguez Rodríguez, E. M., Sanz Alaejos, M., \& Díaz Romero, C. (1999). Chemometric studies of several minerals in milks. Journal of Agricultural and Food Chemistry, 47 (4), 1520-1524.

Sikirić, M., Brajenović, N., Pavlović, I., Havranek, J. L., \& Plavljanić, N. (2003). Determination of metals in cow's milk by flame atomic absorption spectrophotometry. Czech Journal of Animal Science, 48(11), 481-486.

Simsek, O., Gültekin, R., Öksüz, O., \& Kurultay, S. (2000). The effect of environmental pollution on the heavy metal content of raw milk. Nahrung, 44(5), 360-363.

Smart, M. E., \& Christensen, D. A. (1985). The effect of cow's dietary copper intake, sire breed, and age on her copper status and that of her fetus in the first ninety days of gestation. Canadian Journal of Comparative Medicine, 49(2), 156-158.

Sprinkle, J. E., Cuneo, S. P., Frederick, H. M., Enns, R. M., Schafer, D. W., Carstens, G. E., et al. (2006). Effects of a long-acting, trace mineral, reticulorumen bolus on range cow productivity and trace mineral profiles. Journal of Animal Science, 84(6), 1439-1453.

Stawarz, R., Formicki, G., \& Massányi, P. (2007). Daily fluctuations and distribution of xenobiotics, nutritional and biogenic elements in human milk in Southern Poland. Journal of Environmental Science and Health, Part A: Toxic/Hazardous Substances \& Environmental Engineering, 42(8), 1169-1175.

Swarup, D., Patra, R. C., Naresh, R., Kumar, P., \& Shekhar, P. (2005). Blood lead levels in lactating cows reared around polluted localities; transfer of lead into milk. Science of the Total Environment, 347(1-3), 106-110.

Tomza-Marciniak, A., Pilarczyk, B., Bąkowska, M., Pilarczyk, R., Wójcik, J., Marciniak, A., et al. (2011). Relationship between selenium and selected heavy metals concentration in serum of cattle from a non-polluted area. Biological Trace Element Research, 144(1-3), 517-524.

Tripathi, R. M., Raghunath, R., Sastry, V. N., \& Krishnamoorthy, T. M. (1999). Daily intake of heavy metals by infants through milk and milk products. Science of the Total Environment, 227(2-3), 229-235.

Vromman, V., Saegerman, C., Pussemier, L., Huyghebaert, A., De Temmerman, L., Pizzolon, J. C., et al. (2008). Cadmium in the food chain near non-ferrous metal production sites. Food Additives and Contaminants: Part A, 25(3), 293-301.

Wang, Y., Ou, Y. L., Liu, Y. Q., Xie, Q., Liu, Q. F., Wu, Q., et al. (2012). Correlations of trace element levels in the diet, blood, urine, and feces in the Chinese male. Biological Trace Element Research, 145(2), 127-135.

Ward, J. D., Spears, J. W., \& Gengelbach, G. P. (1995). Differences in copper status and copper metabolism among Angus, Simmental, and Charolais cattle. Journal of Animal Science, 73(2), 571-577.

Wiener, G., Russell, W., \& Field, A. C. (1980). Factors influencing the concentration of minerals and metabolites in the plasma of cattle. Journal of Agricultural Science, 94(2), 369-376. 